\title{
In vitro rumen fermentability kinetics of parboiled rice bran
}

\author{
R. Fidriyanto*, R. Ridwan, Rohmatussolihat, W. D. Astuti, N. F. Sari, E. B. M. Adi, \\ E. S. Mulyaningsih and Y. Widyastuti \\ Research Center for Biotechnology, Indonesian Institute of Sciences, \\ Jl. Raya Bogor km 46, Cibinong, Bogor, West Java 16911 - Indonesia \\ *Corresponding E-mail :rusli.sbh@gmail.com
}

Received June 07, 2018; Accepted November 26, 2018

\begin{abstract}
ABSTRAK
Produk beras pratanak telah diproduksi secara luas oleh industri di negara-negara berkembang. Peningkatan produk beras pratanak menyebabkan meningkatnya limbah dedak. Tujuan dari penelitian ini adalah untuk mengetahui pengaruh proses pembuatan beras pratanak terhadap nutrisi dedak dan mengevaluasi nilai nutrisi dan karakteristik dedak padi pratanak dalam fermentasi rumen menggunakan metode kecernaan secara in vitro. Percobaan dilakukan dengan rancangan acak lengkap faktorial dengan 2 faktor dan 3 ulangan Faktor pertama adalah jenis dedak padi yang berasal dari 4 varietas tanaman padi yang terdiri dari LIPI GO1, LIPI GO2, LIPI GO4, dan Sintanur. Faktor kedua adalah waktu perendaman berbeda terdiri dari 0 menit (kontrol), 30 menit dan 60 menit. Data dianalisis dengan menggunakan ANOVA dan signifikansi dari masing-masing perlakuan dianalisis lebih lanjut dengan menggunakan uji Duncan multiple range $(\mathrm{P}<0,05)$. Parameter kinetika dihitung dengan persamaan Ørskov melalui analisa regresi non-linear. Hasil penelitian menunjukkan bahwa kualitas dedak padi pratanak dipengaruhi secara signifikan oleh proses parboiling seperti periode perendaman dan varietas padi. Komposisi kimia, produksi gas rumen, dan kecernaan dedak pratanak berbeda-beda tergantung pada varietas padi. Perendaman selama 30 menit dan 60 menit menurunkan bahan organik, protein kasar, dan meningkatkan serat kasar $(\mathrm{p}<0,05)$. Selain itu, perendaman gabah selama 60 menit meningkatkan lemak kasar. Semakin lama periode perendaman menyebabkan berkurangnya total gas, produksi gas potensial, laju produksi gas dan jumlah kecernaan bahan organik $(\mathrm{P}<0,05)$.

Keywords: Dedak padi pratanak, perendaman, kecernaan, in vitro
\end{abstract}

\begin{abstract}
Parboiled rice product has been widely produced by industry in the developing countries. The increasing of parboiled rice product will consequently increased rice bran waste. Therefore, the objective of the study was to analyze the effect of parboiling processes on nutritional value of rice bran and evaluate nutritional value of parboiled rice bran in the rumen fermentation using in vitro digestibility method. The experiment was arranged in completely randomized factorial design with 2 factors and 3 replications. The first factor is types of rice bran from different rice plant variety consisted of LIPI GO1, LIPI GO2, LIPI GO4, and Sintanur. The second factor is soaking time consist of 0 minute (control), 30 minutes and 60 minutes. Data were analyzed by using ANOVA and significant effects of each treatment were further analyzed by using the least significant difference by Duncan multiple range test $(\mathrm{P}<0.05)$. Kinetic parameters of Ørskov's equation were obtained by non-linear regression procedure. Results showed that the quality of parboiled rice bran was significantly affected by the parboiling process such as soaking periods and rice variety. Chemical composition, rumen gas production, and digestibility of rice bran differ depends on rice variety. Soaking for 30 minutes and 60 minutes decreased organic matter, crude protein, and increased crude fiber $(\mathrm{P}<0.05)$. Moreover, soaking rice grain for 60 minutes
\end{abstract}


increased crude fat. The longer of soaking periods decreased of total gas, potential gas production, gas production rate and total organic matter digestibility $(\mathrm{P}<0.05)$.

Keywords: parboiled rice bran, soaking periods, rice variety, digestibility, in vitro

\section{INTRODUCTION}

Rice bran, the major cereal by-product of rice industry approximately for $5-8 \%$ of milled rice (Sereewatthanawut et al., 2008; Sumantha et al., 2006). It contains $14-16 \%$ protein, $12-23 \%$ fat, $8-10 \%$ crude fiber (Kahlon, 2009; Malekian et al., 2000). The majority of rice bran produced in the world is utilized as raw material of concentrate feed for energy resources (Hagl et al., 2013). Many reports indicate that feeding cattle with rice bran could increase average body weight (Forster et al., 1993; Till et al., 1991; Choi et al, 2016). However, the quality of rice bran is influence by varieties and paddy treatment before grinding.

Parboiled rice product has been widely produced by industry in the developing countries. Currently, the use of Parboiling technology provides promising opportunities to improve rice nutrition. The parboiling process is done before the hulls are removed and consist of three-stage process namely soaking, steaming and drying (Fernandes, 2016). The increasing of parboiled rice product consequently increased rice bran waste. All processes on parboiling method have impacts on the quality of parboiled rice. Parboiling process could increase nutrition of rice by transfer nutrition content from bran into the inner layers of rice caryopsis and decreased percentage of broken grain (Levien et al., 2015). This Transfer nutrition will be effected on nutritional quality of rice bran as feedstuff. However, little is known about the influence of parboiling processes on the nutritional value of rice bran. Therefore, the objective of the study was to analyze the effect of parboiling processes on nutritional value of rice bran and evaluate nutritional value of parboiled rice bran in the rumen fermentation using in vitro digestibility method.

\section{MATERIALS AND METHODS}

\section{Materials}

Rice grains were consist of 4 different varieties i.e. LIPI GO1, LIPI GO 2, LIPI GO 4 and Sintanur. Rice grains of LIPI GO were obtained from Laboratory of Agronomy for
Evaluation of Product Biotechnology, Research Center for Biotechnology, Indonesian Institutes of Sciences, while Sintanur was obtained from Indonesian Center for Rice Research, Ministry of Agriculture Republic Indonesia.

\section{MATERIALS AND METHODS}

\section{Parboiled Rice Bran.}

One $\mathrm{kg}$ of rice grain were soaked into $60^{\circ} \mathrm{C}$ (1:2) water for 30 and 60 minutes. After soaking process, rice grains were put into cheesecloth and steamed by autoclave at $121^{\circ} \mathrm{C} 1 \mathrm{~atm}$ for 15 minutes. Thereafter, the samples were dried in a cabinet drier at $40^{\circ} \mathrm{C}$ for about $24 \mathrm{~h}$. The dried sample was hulled to get rice bran. Rice brand were milled into 18 mesh flour and stored in polyethylene bags at $4^{\circ} \mathrm{C}$ prior to analysis.

\section{Experiment}

The experiment was arranged in completely randomized factorial design with 2 factors and 3 replications. The first factor is types of rice bran from different rice plant variety consisted of LIPI GO1, LIPI GO2, LIPI GO4, and Sintanur. The second factor is soaking time consist of 0 minute (control), 30 minute and 60 minute. The dried sample of parboiled rice bran was analyzed for $\mathrm{pH}$, Proximate analysis (dry mater, crude protein, ash content, crude fiber and crude fat content (AOAC 2005). In vitro fermentation was conducted according to the method of Theodorou et al., (1994) with modification. Rumen fluid were collected from two rumen-fistulated Ongole crossbred cattle before morning feeding. The rumen-fistulated Ongole crossbred cattle were managed according to the protocols approved by the Ethic Clearance Committee of Indonesian Institute of Sciences (Number 9879/WK/HK/XI/2015). Rumen fluid that used for in vitro studies was filtered using double layer of cheesecloth, pooled in thermos, sealed and immediately transported to the laboratory. Into each fermentation bottle, $0.5 \mathrm{~g}$ substrate and 50 $\mathrm{mL}$ mixture solution of McDougall buffer and rumen fluid (3:1) were added. The tubes were flushed by $\mathrm{CO}_{2}$ for $60 \mathrm{~s}(\mathrm{pH}$ 6.5-6.9) and incubated in water bath at temperature of $39^{\circ} \mathrm{C}$. Gas production was measured at $2 \mathrm{~h}, 4 \mathrm{~h}, 6 \mathrm{~h}, 8 \mathrm{~h}$, 
$10 \mathrm{~h}, 12 \mathrm{~h}, 24 \mathrm{~h}$, and $48 \mathrm{~h}$ of incubation to obtain kinetics gas production. After $48 \mathrm{~h}$ of incubation, $\mathrm{pH}$ value of rumen-buffer mixture were analyzed. Thereafter, rumen-buffer mixture was separate using Whatman ${ }^{\mathrm{TM}}$ papers no 41 (CAT No.1441125). Dry matter and organic matter disappearance (DMRD and OMRD) were measured after $48 \mathrm{~h}$ of fermentation, while dry matter and organic matter digestibility (DMD and OMD) were measured after $2 \times 48 \mathrm{~h}$ of fermentation, with the addition of pepsin- $\mathrm{HCl}$ after $48 \mathrm{~h}$ of fermentation.

\section{Statistical Analysis}

Data of proximate, gas production, rumen feed disappearance, and Volatile fatty acid production were analyzed by using ANOVA with SPSS 23 for windows. Significant effects of each treatment were further analyzed by using the least significant difference by Duncan multiple range test $(\mathrm{P}<0.05)$. Data of gas production were adjusted at the model proposed by Ørskov \& McDonald (1979) as $\mathrm{p}=\mathrm{a}+\mathrm{b}\left(1-\mathrm{e}^{-\mathrm{ct}}\right)$ that $\mathrm{P}$ is the gas produced at time $t$, ' $a$ ' is gas produced by the soluble fraction, ' $b$ ' is gas produced by the insoluble but slowly fermenting fraction, ' $c$ ' is constant gas production rate, ' $t$ ' is time of fermentation. Kinetic parameters of Ørskov's equation were obtained by non-linear regression procedure in SPSS 23.

\section{RESULTS AND DISCUSSIONS}

Rice bran, a valuable by product contains of essential nutrients such as protein, minerals, vitamins, fiber, amino acids and antioxidants (Younas et al., 2011). Compositional data from parboiled rice bran samples are presented in Table 1. Crude protein content of the different rice brans was low, ranging between $4,2 \%$ and $4,77 \%$ and this result were lower than in other studies. Rice bran contains about $10-15 \%$ of high quality protein (Lean, 2014). The highest crude protein content in rice grain is on the outer surface of rice kernel and in bran (Champagne et al., 2004). There was no significant different on 4 varieties of rice bran on dry matter, crude fiber and crude fat but organic matter and crude protein content of LIPI GO4 was significantly higher $(\mathrm{p}<0.05)$. Significant differences $(\mathrm{P}<0.05)$ existed between the samples and these variations may be attributed to varietal differences. The nutritional composition of rice bran is depends on rice variety (Amissah et al., 2003).
Soaking rice grain for 30 minutes and 60 minutes followed by steaming decreased organic mater $81.90 \%$ and $82.43 \%$, crude protein $3.68 \%$ and $3.96 \%$ and increased crude fiber $34.94 \%$ and $37.79 \%$, respectively $(\mathrm{p}<0.05)$. Milled parboiled rice has been found to have greater amounts of nutrition compound and certain minerals as compared with milled raw rice (Bhattacharya et al., 2013) The changes of nutrition of parboiled rice was caused by internal migration of watersoluble small molecules from the bran layer into the endosperm during soaking process. The migration of water-soluble small molecules will decreased nutrition compound on rice bran. Soaking rice grain for 60 minute increased crude fat $4.29 \%(\mathrm{p}<0.05)$. Rice bran is mainly composed of the aleurone layer and embryo, and contains $60 \%$ of non-starch lipids that are the major lipids present in bran layer as spherosomes (Godber and Juliano, 2004). Lipid are broken and released from the surface of kernel during parboiling process. Lipids are diffused into bran layer of parboiled rice and make bran become oily (Mahadevappa and Desikachar, 1968).

Several studies have evaluated the effects of soaking temperature and steaming duration in parboiled rice. Soaking had significant effect on chemical compositions of rice grains mainly on starch content. Decrease in starch content after soaking might be due to leaching and formation of amyloselipid complexes during heating in water (Singh et al., 2006; Derycke et al., 2005). Soaking and steaming might also have same effect on rice bran. The formation of amyloselipid made rumen microbes harder to degrade and lead to decreased of gas production.

The organic matter was decreased during the increasing of soaking periods (Table 1). Decreased of mineral in rice bran might be due to leaching of minerals from the husk and bran into the starchy endosperm during soaking process. Minerals leached into the soaking water and also diffused into the endosperm of rice (Derycke et $a l, 2005)$.

In vitro method was used to estimate digestibility of parboiled rice bran on rumen and post rumen digestibility. Digestibility of parboiled rice bran in the rumen was indicated by DMDR and OMDR parameters. There was no significant different on DMDR and OMDR. Ruminal $\mathrm{pH}$ and OMD was significantly affected $(\mathrm{P}<0.05)$ by soaking time (Table 2) but not affected $(\mathrm{P}<0.05)$ by variety of rice bran. Despite of an increase in $\mathrm{pH}$ value due to the soaking treatment, the $\mathrm{pH}$ 
Table 1. Nutritional Value from Different Soaking Periods and Types of Rice Bran

\begin{tabular}{lccccc}
\hline \multirow{2}{*}{\multicolumn{1}{c}{ Variable }} & DM (\%) & OM (\%) & CP (\%) & EE (\%) & CF (\%) \\
\cline { 2 - 6 } Types of Rice Bran mean (T) & \multicolumn{5}{c}{$\%$ DM Basis } \\
LIPI GO1 & 95.19 & $84.78^{\mathrm{c}}$ & $4.20^{\mathrm{a}}$ & 3.78 & 34.72 \\
LIPI GO2 & 94.87 & $84.04^{\mathrm{b}}$ & $4.18^{\mathrm{a}}$ & 3.52 & 33.85 \\
LIPI GO4 & 95.67 & $85.06^{\mathrm{c}}$ & $4.77^{\mathrm{b}}$ & 3.52 & 33.25 \\
SINTANUR & 95.15 & $78.61^{\mathrm{a}}$ & $4.18^{\mathrm{a}}$ & 3.56 & 32.44 \\
P-Value & & & & & \\
Types of Rice (T) & $>0.05$ & $<0.05$ & $<0.05$ & $>0.05$ & $<0.05$ \\
Soaking periods mean (S) (Minute) & & & & & \\
0 & 94.58 & $85.03^{\mathrm{c}}$ & $5.36^{\mathrm{a}}$ & $3.13^{\mathrm{a}}$ & $27.95^{\mathrm{a}}$ \\
30 & 95.90 & $81.90^{\mathrm{a}}$ & $3.68^{\mathrm{b}}$ & $3.36^{\mathrm{a}}$ & $34.94^{\mathrm{b}}$ \\
60 & 95.18 & $82.43^{\mathrm{b}}$ & $3.96^{\mathrm{b}}$ & $4.29^{\mathrm{b}}$ & $37.79^{\mathrm{c}}$ \\
P-Value & & & & & \\
Soaking periods & $>0.05$ & $<0.05$ & $<0.05$ & $<0.05$ & $<0.05$ \\
P-Value & & & & & \\
Interaction (T x S) & $>0.05$ & $>0.05$ & $>0.05$ & $>0.05$ & $<0.05$ \\
\hline
\end{tabular}

DM: dry matter; OM: organic matter; CP: crude protein; EE: Ether Extract; CF:Crude Fiber

${ }^{\mathrm{a}-\mathrm{c}}$ Means with different superscripts within columns significantly differed $(\mathrm{P}<0.05)$.

value was still within the normal $\mathrm{pH}$ range of the rumen. The normal rumen $\mathrm{pH}$ range is between 5.8 to 6.9 (Morgante et al., 2009). The increased of $\mathrm{pH}$ could be explained by higher fat content, lower fiber content, lower OM digestibility and lower potential gas production of parboiled rice bran. Soaking treatment of rice bran for 30 minutes decreased OMD $(\mathrm{P}<0.05)$ by $25,68 \%$. The decreased of OMD was caused by the increased of crude fiber and crude fat content and decreased of protein content. Higher fat content has negative effects on digestibility and fermentation of feeds including animal performance (Kumar, 2013). High fiber in the feed will cause the process of fermentation in the rumen run slowly, thus avoiding the rapid increase of gas production and acid too quickly in the rumen, which could depress $\mathrm{pH}$ and fiber fermentation and lead to digestive upset (Lean 2014)

Different types of rice bran affected potential gas production, gas production rate, and total gas production $(\mathrm{P}<0.05)$ as presented in Table 3.
Chemical composition of rice bran differ depends on rice variety, climatic conditions, and rice processing methods (Taylor et al. 2011). Differences in chemical composition of feed ingredients will affected rumen gas production. Production of gas in the rumen related to rumen microbial activities. The kinetic gas production are presented in Figure 1. LIPI GO 4 rice bran without soaking treatment was shown the highest gas production and gas production rate. The increasing of soaking periods was decreased gas production and gas production rate.

The increasing of the soaking period will decrease the total gas production, gas production potential, and gas production rate $(\mathrm{P}<0.05)$. Decreased of gas production was supported by a decrease in protein levels and organic matter. Rice bran surface protein during parboiled rice making process play role in water diffusion. Because the glass transition of surface protein is slightly lower than starch, surface protein may acts as a regulator of water diffusion into the starch granules and controls granular swelling during the 
Table 2. Digestibility from Different Soaking Periods and Types of Rice Bran

\begin{tabular}{lccccc}
\hline \multirow{2}{*}{ Variable } & $\mathrm{pH}$ & DMDR & OMDR & DMD & OMD \\
\cline { 3 - 6 } & & & \multicolumn{4}{c}{ \%DM Basis } \\
\hline Types of Rice Bran mean (T) & 6.39 & $46.70^{\mathrm{a}}$ & 51.63 & 46.77 & 52.39 \\
LIPI GO1 & 6.35 & $37.46^{\mathrm{a}}$ & 51.45 & 34.04 & 48.8 \\
LIPI GO2 & 6.32 & $22.52^{\mathrm{b}}$ & 42.03 & 32.04 & 47.37 \\
LIPI GO4 & 6.37 & $20.29^{\mathrm{b}}$ & 37.59 & 35.60 & 46.97 \\
SINTANUR & & & & & \\
P-Value & $>0.05$ & $<0.05$ & $>0.05$ & $>0.05$ & $>0.05$ \\
Types of Rice (T) & & & & & \\
Soaking periods mean (S) (Minute) & & & & \\
0 & $6.30^{\mathrm{a}}$ & 31.33 & 53.96 & 41.28 & $57.51^{\mathrm{b}}$ \\
30 & $6.39^{\mathrm{b}}$ & 29.98 & 42.72 & 32.28 & $42.74^{\mathrm{a}}$ \\
60 & $6.39^{\mathrm{b}}$ & 33.92 & 40.27 & 37.77 & $46.41^{\mathrm{ab}}$ \\
P-Value & & & & & \\
Soaking periods & $<0.05$ & $>0.05$ & $>0.05$ & $>0.05$ & $<0.05$ \\
P-Value & & & & & \\
Interaction (T x S) & $>0.05$ & $>0.05$ & $>0.05$ & $>0.05$ & $>0.05$ \\
\hline
\end{tabular}

DMRD: dry matter disappearance, OMRD: organic matter disappearance, DMD dry matter digestibility, OMD: organic matter digestibility

${ }^{\mathrm{a}-\mathrm{c}}$ Means with different superscripts within columns significantly differed $(\mathrm{P}<0.05)$

gelatinization process and make water absorption capacity become higher (Matveev et al., 2000). During gelatinization process, the starch and protein expand and fill in the internal spaces between granules and created strong cohesion between them (Islam, 2004; Sareepuang et al., 2008). Strong cohesion between starch granule in rice bran make protein and starch become harder to degrade by rumen microbes and decreased organic matter and dry matter digestibility and total gas production. Decreased of organic matter in rice bran means decreased of nutrients content in feed which can used by rumen microbes for growth. Nutrient such as protein and starch partly converted by rumen microbe into volatile fatty acid.

Matrix correlation between nutritional compound, variable, and parameter of in vitro digestibility of parboiled rice bran are presented in Table 4. The results showed, crude fat had negative correlation with rumen $\mathrm{pH}$ value
$(\mathrm{P}<0.05)$. Fat content in feed become inhibitor for rumen microbial growth. Crude protein had negative correlation with $\mathrm{pH}$ value and positive correlation with $\mathrm{OMD}$, potential gas production, and total gas production $(\mathrm{P}<0.05)$. Protein is easy to be digested in rumen by rumen microbe except protein which protected with certain compound. Protein will be hydrolyzed by rumen microbe and turn into ammonia and amino acids (Neeta Agarwal and Chaudhary 2015). As the decrease of protein compound in feedstuff, there is generally a corresponding increasing rumen $\mathrm{pH}$ values.

Crude fiber showed positive correlation with $\mathrm{pH}$ value and negative correlation with OMD, potential gas production, and total gas production $(\mathrm{P}<0.05)$. Fiber consist of acid detergent fiber (ADF) and neutral detergent fiber (NDF). Fiber is required to maintain normal ruminal $\mathrm{pH}$, stimulating rumination, promoting dilution of more fermentable components of the feed, and favors ruminal buffering, but large amounts 
Table 3. Gas Production Kinetic from Different Soaking Periods and Types Rf Bice bran

\begin{tabular}{lccc}
\hline \multicolumn{1}{c}{ Variable } & PGP $(\mathrm{mL})$ & GPR $(\mathrm{mL} / \mathrm{hr})$ & Total Gas $(\mathrm{mL})$ \\
\hline Types of Rice Bran mean (T) & & & \\
LIPI GO1 & $35.96^{\mathrm{a}}$ & $0.037^{\mathrm{a}}$ & $29.089^{\mathrm{a}}$ \\
LIPI GO2 & $37.20^{\mathrm{a}}$ & $0.039^{\mathrm{a}}$ & $31.44^{\mathrm{a}}$ \\
LIPI GO4 & $48.56^{\mathrm{b}}$ & $0.052^{\mathrm{b}}$ & $44.78^{\mathrm{b}}$ \\
SINTANUR & $47.02^{\mathrm{b}}$ & $0.055^{\mathrm{b}}$ & $42.72^{\mathrm{b}}$ \\
P-Value & & & \\
Types of Rice (T) & $<0.05$ & $<0.05$ & $<0.05$ \\
Soaking periods mean (S) (Minute) & & & \\
0 & $63.18^{\mathrm{b}}$ & 0.047 & $56.72^{\mathrm{a}}$ \\
30 & $31.37^{\mathrm{a}}$ & 0.044 & $26.86^{\mathrm{b}}$ \\
60 & $31.99^{\mathrm{a}}$ & 0.042 & $27.44^{\mathrm{b}}$ \\
P-Value & & & \\
Soaking periods & $<0.05$ & $>0.05$ & $<0.05$ \\
P-Value & & & $>0.05$ \\
Interaction (Tx S) & $>0.05$ & $>0.05$ & \\
\hline
\end{tabular}

PGP: potential gas production, GPR: gas production rate

${ }^{\mathrm{a}-\mathrm{c}}$ Means with different superscripts within columns significantly differed $(\mathrm{P}<0.05)$.

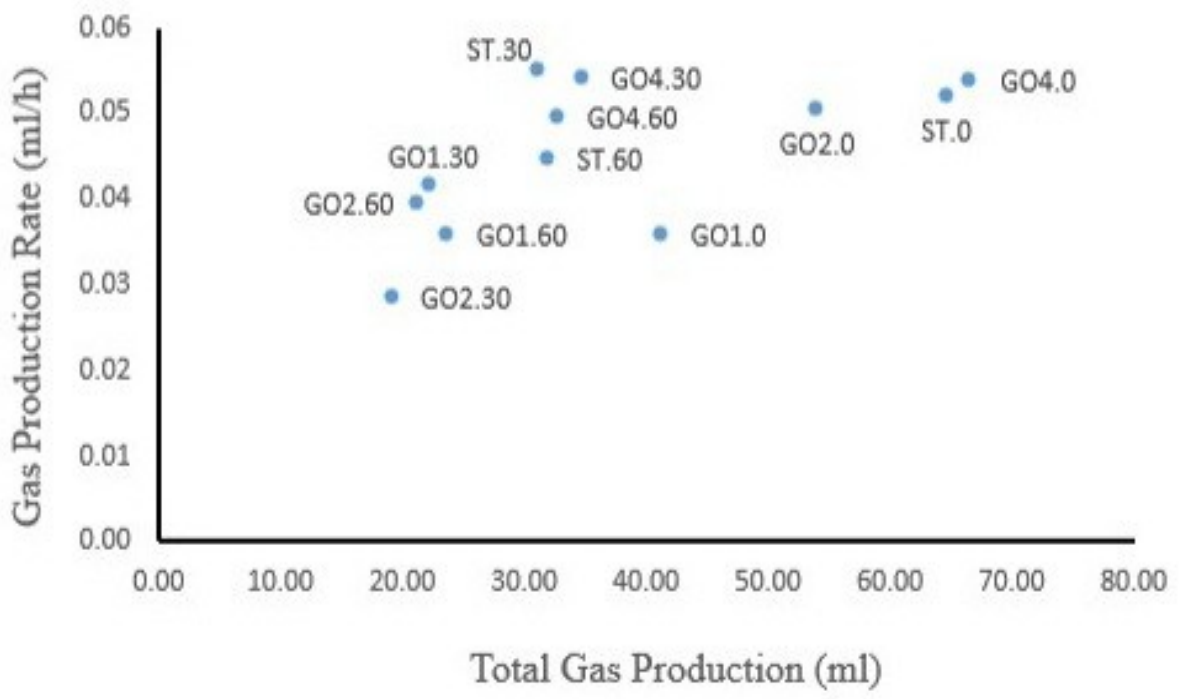

Figure 1. In vitro Gas Production Kinetics of Parboiled Rice Bran 


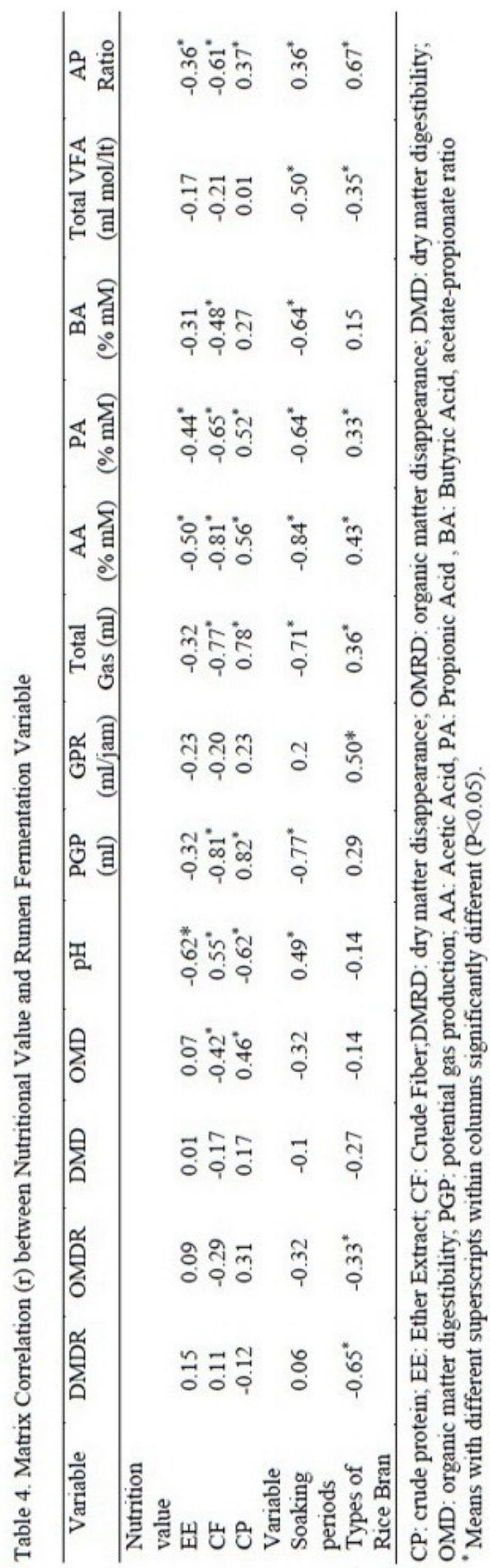

consumption of NDF will decreased feed intake (Rodrigues, 2016; Zebeli et al. 2012).

Main VFA in the rumen are propionate, butyrate, acetate; and small portion of isobutyrate, valerate, isovalerate, and caproate (McDonald et al., 2011). The result showed (Table. 5) the longer the soaking periods will cause the decline concentration of total VFA, acetic acid, propionic acid, butyric acid and valeric acid $(\mathrm{P}<0.05)$. The decreased concentrations of volatile acids could be the response of the lower fermentation activity due to the decreasing of rice bran nutrient during the soaking process. The decreasing of VFA concentration was followed by decreased of digestibility and increased of $\mathrm{pH}$. There is a positive correlation between DM digestibilities with ruminal total VFA production. Feed with low DM digestibility can contribute to low ruminal total VFA production (Cao et al, 2011).

The increasing of soaking periods followed by decreased $\mathrm{A} / \mathrm{P}$ ratio $(\mathrm{P}<0.05)$ cause of lower acetate and higher propionate. The decrase of $\mathrm{A} / \mathrm{P}$ ratio means an increase in propionate proportion. The proportion of VFA in the rumen is affected by diets, microbial growth rates, levels of feeding, and ruminal $\mathrm{pH}$ (López et al., 2000). Probably, the decreased of $\mathrm{A} / \mathrm{P}$ ratio cause by steaming treatment and the increasing of starch content of rice bran from 5,96\% ( 0 minute) to $6.95 \%$ (30 minutes) and $15.20 \%$ (60 minutes) respectively (data unpublished). Steaming treatment on grain increased proportion of propionic acid and decreased ratio of acetic acid to propionic acid (Lee et al., 1982; Zinn, 1987; Barajas and Zinn, 1998; Quiao et al., 2015) The high portion of fibrous diet will result in the production of large amounts of acetate and butyrate, whereas the high starch diet results in a greater proportion of propionate, although acetate is still the dominant VFA (Beever and Mould, 2000; Gonzalez et al., 2012; Li et al., 2014).

\section{CONCLUSION}

The quality of rice bran from parboiled rice depends on rice variety and parboiling process. Parboiled rice bran had lower organic matter and crude protein content but higher in fat content and crude fiber content compared with non-parboiled rice. The increasing of rice grain soaking periods, decreased total gas production, gas production rate, potential gas production rate, organic matter digestibility and total VFA. Rice bran from parboiled rice waste had lower nutrition than rice 
Table 5. Volatile Fatty Acid on In vitro Rumen Feed Digestibility from Different Soaking Periods and Types of Rice Bran

\begin{tabular}{|c|c|c|c|c|c|c|}
\hline Variable & $\begin{array}{c}\mathrm{AA} \\
(\mathrm{mL} \mathrm{mol} / \mathrm{lt})\end{array}$ & $\begin{array}{c}\mathrm{PA} \\
(\mathrm{mL} \mathrm{mol} / \mathrm{lt})\end{array}$ & $\begin{array}{c}\text { BA } \\
(\mathrm{mL} \mathrm{mol} / \mathrm{lt})\end{array}$ & $\begin{array}{c}\mathrm{VA} \\
(\mathrm{mL} \mathrm{mol} / \mathrm{lt})\end{array}$ & $\begin{array}{l}\text { Total VFA } \\
(\mathrm{mL} \mathrm{mol} / \mathrm{lt})\end{array}$ & A/P Ratio \\
\hline \multicolumn{7}{|l|}{$\begin{array}{l}\text { Types of Rice Bran } \\
\text { mean }(\mathrm{T})\end{array}$} \\
\hline LIPI GO1 & $38.95^{\mathrm{a}}$ & $16.91^{\mathrm{a}}$ & $8.15^{\mathrm{b}}$ & $2.22^{\mathrm{c}}$ & $66.26^{\mathrm{a}}$ & $2.29^{\mathrm{b}}$ \\
\hline LIPI GO2 & $38.87^{\mathrm{a}}$ & $17.78^{\mathrm{b}}$ & $8.18^{\mathrm{b}}$ & $1.67^{\mathrm{ab}}$ & $66.52^{\mathrm{a}}$ & $2.17^{\mathrm{a}}$ \\
\hline LIPI GO4 & $43.11^{b}$ & $19.60^{\mathrm{c}}$ & $7.65^{\mathrm{a}}$ & $1.54^{\mathrm{a}}$ & $71.92^{b}$ & $2.19^{\mathrm{a}}$ \\
\hline SINTANUR & $45.59^{\mathrm{c}}$ & $17.83^{\mathrm{b}}$ & $8.78^{\mathrm{c}}$ & $1.79^{\mathrm{b}}$ & $73.99^{\mathrm{c}}$ & $2.55^{\mathrm{c}}$ \\
\hline P-Value & $<0.05$ & $<0.05$ & $<0.05$ & $<0.05$ & $<0.05$ & $<0.05$ \\
\hline \multicolumn{7}{|c|}{$\begin{array}{l}\text { Soaking periods mean } \\
\text { (S) (Minute) }\end{array}$} \\
\hline 0 & $48.39^{\mathrm{a}}$ & $19.23^{\mathrm{c}}$ & $8.97^{\mathrm{c}}$ & $2.01^{\mathrm{a}}$ & $78.61^{\mathrm{c}}$ & $2.53^{\mathrm{a}}$ \\
\hline 30 & $40.86^{\mathrm{b}}$ & $18.07^{\mathrm{b}}$ & $8.16^{\mathrm{b}}$ & $1.95^{\mathrm{b}}$ & $69.05^{\mathrm{b}}$ & $2.26^{\mathrm{b}}$ \\
\hline 60 & $35.65^{\mathrm{c}}$ & $16.79^{\mathrm{a}}$ & $7.44^{\mathrm{a}}$ & $1.45^{\mathrm{b}}$ & $61.35^{\mathrm{c}}$ & $2.21^{\mathrm{c}}$ \\
\hline P Value & $<0.05$ & $<0.05$ & $<0.05$ & $<0.05$ & $<0.05$ & $<0.05$ \\
\hline Interaction $(\mathrm{T} \times \mathrm{S})$ & $>0.05$ & $<0.05$ & $<0.05$ & $<0.05$ & $>0.05$ & $<0.05$ \\
\hline
\end{tabular}

AA: acetic acid, PA: propionic acid, BA: butyric acid, VA: valeric acid, A/P Ratio : acetate-propionate ratio ${ }^{a-c}$ Means with different superscripts within columns significantly differed $(\mathrm{P}<0.05)$

bran from common rice.

\section{ACKNOWLEDGMENTS}

The authors wish to acknowledge the financial support received from "DIPA" Biovillage 2017 and Technopark Banyumulek NTB 2017 of the Research Center for Biotechnology Indonesian Institute of Science.

\section{REFERENCES}

Amissah, J. G. N., W. O. Ellis, I. Oduro, and J. T. Manful. 2003. Nutrient composition of bran from new rice varieties under study in Ghana. Food Control. 14:21-24.

AOAC. 2005. Official Methods of Analysis of AOAC International, 18th edition. AOAC International, Gaitherburg.

Bhattacharya, K. R. 2013. Effect of Parboiling on Rice Quality. In: Rice Quality. Woodhead Publishing Limited, Cambridge. P. 247-297

Blaak, E. E., J. M. Antoine, D. Benton, I. Björck,
L. Bozzetto, F. Brouns, M. Diamant, L. Dye, T. Hulshof, J. J. Holst, D. J. Lamport, M. Laville, C. L. Lawton, A. Meheust, A. Nilson, S. Normand, A. A. Rivellese, S. Theis, S. S. Torekov, and S. Vinoy. 2012. Impact of postprandial glycaemia on health and prevention of disease. Obesity Reviews. 13:923-984.

Boers, H. M., J. Seijen, and D. J. Mela. 2015. Systematic Review A systematic review of the influence of rice characteristics and processing methods on postprandial glycaemic and insulinaemic responses. Br. J. Nutr. 114:1035-1045.

Barajas, R. and Zinn, R.A. 1998. The feeding value of dry-rolled and steam-flaked corn in finishing diets for feedlot cattle: influence of protein supplementation. J Anim Sci. 76: 1744-1752.

Cao, Y., Cai, Y., Takahashi, T. 2011. Effect of lactic acid bacteria inoculant and beet pulp addition on fermentation characteristics and in vitro ruminal digestion of vegetable 
residue silage. J. Dairy Sci. 94: 3902-3912.

Derycke, V., G. E. Vandeputte, R. Vermeylen, W. De Man, and B. Goderis. 2005. Starch gelatinization and amylose - lipid interactions during rice parboiling investigated by temperature resolved wide angle X-ray scattering and differential scanning calorimetry. J. Cereal Sci. 42:334343.

Fernandes, F., N. Levien, J. D. J. Berrios, V. Zanella, D. Wood, T. Williams, J. Pan, and M. Cardoso. 2016. Polishing and parboiling effect on the nutritional and technological properties of pigmented rice. Food Chem. 191:105-112.

Godber, J. S., and B. O. Juliano. 2004. Rice Lipids. In: Rice : chemistry and technology. (Elaine T. Champagne, 3rd eds). American Association of Cereal Chemists, Inc. Minnesota. P. 163-186

Gonzalez, L. A., X. Manteca., S. Calsamiglia., K. S. Schwartzkopf-Genswein., and A. Ferret. 2012. Ruminal acidosis in feedlot cattle: Interplay between feed ingredients, rumen function and feeding behavior (a review). Anim. Feed Sci. Technol. 172:66-79.

Hagl, S., A. Kocher, C. Schiborr, S. H. Eckert, I. Ciobanu, M. Birringer, H. El-Askary, A. Helal, M. T. Khayyal, J. Frank, W. E. Muller, and G. P. Eckert. 2013. Rice bran extract protects from mitochondrial dysfunction in guinea pig brains. Pharmacol. Res. 76:17-27.

Hardini, D. 2010. The Nutrient Evaluation of Fermented Rice Bran as Poultry Feed. International J. Poult. Sci. 9:152-154.

Islam, M. R. 2004. Energy requirement in parboiling and its relationship to some important quality indicators. J. Food Eng. 63:433-439.

Kumar, A. 2013. The effect of dietary fats on methane emissions, and its other effects on digestibility, rumen fermentation and lactation performance in cattle: A metaanalysis. Livest. Sci. 155:244-254.

Lean, I. J. 2014. Controlling Rumen Function Rumen function Carbohydrates Proteins Acidosis Evaluating nutrition. Vet Clin Food Anim. 30:539-575.

Lee, R.W., Gaylean, M. L., Lofgreen, G. P. 1982. Effects of mixing whole shelled and steam flaked corn in finishing diets on feedlot performance and site and extent of digestion in beef steers. J Anim Sci. 55:475-485.
Levien, N., R. Tadeu, and J. D. J. Berrios. 2015. Journal of Food Composition and Analysis Thiamine content and technological quality properties of parboiled rice treated with sodium bisulfite: Benefits and food safety risk. J. Food Compos. Anal. 41:98-103.

Li, F., X. J. Yang, Y. C. Cao, S. X. Li, J. H. Yao, Z. J. Li, and F. F. Sun. 2014. Effects of dietary effective fiber to rumen degradable starch ratios on the risk of sub-acute ruminal acidosis and rumen content fatty acids composition in dairy goat. Anim. Feed Sci. Technol. 189:54-62.

López, S., Dijkstra , J. and France, J. 2000. Prediction of energy supply in ruminants, with emphasis on forages. In : Forage Evaluation in Ruminant Nutrition. (D. I. Givens, E. Owens, R. F. E., Axford and H. M. Omed, eds). Wallingford: CAB International. pp. 63-94

McDonald, P., R. A. Edwards, J. F. D. Greenhalgh, C. A. Morgan, L. A. Sinclair, and R. G. Wilkinson. 2011. Animal Nutrition. 7th edn. Prentice Hall, Harlow, UK

Matveev, Y. I., V. Y. Grinberg, and V. B. Tolstoguzov. 2000. The plasticizing effect of water on proteins, polysaccharides and their mixtures. Glassy state of biopolymers, food and seeds. Food Hydrocolloids 14:425-437.

Morgante, M., M. Gianesella, and S. Casella. 2009. Blood gas analyses, ruminal and blood $\mathrm{pH}$, urine and faecal $\mathrm{pH}$ in dairy cows during sub acute ruminal acidosis. Comp. Clin. Pathol. 18:229-232.

Neeta Agarwal, D. N. K., and L. C. Chaudhary. 2015. Nitrate/Nitrite Toxicity and Possibilities of Their Use in Ruminant Diet. In: Rumen Microbiology: From Evolution to Revolution. (A. K. Puniya, R. Singh, and D. Nandan). Springer. New Delhi. P. 17-30

Qiao, F., Wang, F., Ren L., Zhou, Z., Meng, Q., Bao Y. 2015. Effect of Steam-Flaking on Chemical Compositions, Starch Gelatinization, In vitro Fermentability, and Energetic Values Of Maize, Wheat and Rice. J Int. Agric. 14(5):949-955

Rodrigues, P. H. M. 2016. Rumenology. In: Rumenology. (R. D. L. Pacheco, D. D. Millen, and M. D. B. Arrigoni). Springer International Publishing, Switzerland. P 157-187

Sareepuang, K., S. Siriamornpun, L. Wiset, and N. Meeso. 2008. Effect of Soaking 
Temperature on Physical, Chemical and Cooking Properties of Parboiled Fragrant Rice Research Unit of Drying Technology for Agricultural Products. World J. Agric. Sci. 4:409-415.

Singh, N., L. Kaur, and K. Singh. 2006. Relationships between physicochemical, morphological, thermal, rheological properties of rice starches. Food Hydrocolloids. 20:532-542.

Taylor, P., C. Fabian, Y. Ju, C. Fabian, and Y. Ju. 2011. A Review on Rice Bran Protein: Its Properties and Extraction Methods. Food Sci. Nutr. 51:816-827.

Theodorou, M. K., B. A. Williams, M. S. Dhanoa, A. B. McAllan, and J. France. 1994. A simple gas production method using a pressure transducer to determine the fermentation kinetics of ruminant feeds. Anim. Feed Sci. Technol. 48:185-197.

Younas, A., M. S. Bhatti, A. Ahmed, and M. A. Randhawa. 2011. Effect of rice bran supplementation on quality of bread. Pak. J. Agri. Sci. 48:129-134.

Zebeli, Q., J. R. Aschenbach, M. Tafaj, J. Boguhn, B. N. Ametaj, and W. Drochner. 2012. Invited review: Role of physically effective fiber and estimation of dietary fiber adequacy in high-producing dairy cattle. J. Dairy Sci. 95:1041-1056.

Zinn, R. A. 1987. Influence of lasalocid and monensin plus tylosin on comparative feeding value of steam-flaked versus dryrolled corn in diets for feedlot cattle. J. Anim. Sce. 65:256-266. 